\title{
INTERAÇÕES AFETIVO-SEXUAIS ENTRE MULHERES E NEGOCIAÇÕES COM O CONTEXTO INTERIORANO
}

\author{
AFFECTIVE-SEXUAL INTERACTIONS BETWEEN WOMEN AND \\ NEGOTIATIONS WITH THE INTERIOR CONTEXT
}

\author{
Luis Felipe Rios do Nascimento ${ }^{1}$ \\ Luisa Marianna Vieira da $\mathrm{Cruz}^{2}$
}

\section{RESUMO}

Este trabalho teve como objetivo investigar as estratégias de resistência à heterossexualidade compulsória utilizada por mulheres que mantêm relações afetivo-sexuais com mulheres da cidade de Serra Talhada - PE. Desse modo, foi necessário conhecer como aspectos da territorialidade atravessam como os sujeitos se percebem e no exercício da sua sexualidade. Quanto a metodologia, o trabalho de campo foi construído através das entrevistas com nove mulheres que mantêm relações afetivo-sexuais entre mulheres residentes na cidade de Serra Talhada, utilizando-se de um roteiro com enfoque biográfico. Para selecionar as participantes foi utilizada a amostragem por bola de neve, após a coleta de dados, foi realizada a transcrição das entrevistas e análise temática dos dados. Também foi utilizada a observação participante com intuito de descrever como é Serra Talhada como local de pesquisa, o que auxiliou com a contextualização das narrativas apresentadas. Diante disso, relataram acerca as interações afetivo-sexuais e negociações necessárias para vivenciar uma sexualidade dissidente em uma cidade de pequeno porte. Por fim, delinearam como é resistir ao controle, vigilância, a pessoalidade tão fortemente marcado no contexto.

Palavras-chaves: Homossexualidade Feminina. Heterossexualidade Compulsória. Território.

\begin{abstract}
This study aimed to investigate the strategies of resistance to compulsory heterosexuality used by women who maintain affective-sexual relationships with women in the city of Serra Talhada-PE. In this way, it was necessary to know how aspects of territoriality cross how subjects perceive themselves and in the exercise of their sexuality. As for the methodology, fieldwork was constructed through interviews with nine women who maintain affective-sexual relationships among women living in the city of Serra Talhada, using a script with a biographical approach. In order to select the participants, snowball sampling was used, after data collection, transcription of interviews and thematic analysis of the data
\end{abstract}

\footnotetext{
${ }^{1}$ É professor Associado IV da Universidade Federal de Pernambuco onde atua no curso de graduação em Psicologia (desde 2004), no Programa de Pós-graduação em Psicologia (desde 2006). Doutorado em Saúde Coletiva (2000-2004) pela Universidade do Estado do Rio de Janeiro e pós-doutorado em Psicologia Social (20172018) pela Universidade de São Paulo. e-mail: 1felipe.rios@gmail.com

2 Mestra em Psicologia na UFPE.. Psicóloga no Centro de Atenção Psicossocial- Álcool e outras drogas (CAPSadIII) - Serra Talhada. e-mail: 1ucruzst@gmail.com
} 


\section{Revista \\ Debates Insubmissos}

were performed. Participant observation was also used in order to describe how Serra Talhada is a research site, which helped with the contextualization of the narratives presented. They reported on the affective-sexual interactions and negotiations needed to experience a dissident sexuality in a small town. Finally, they outlined how it is to resist control, vigilance, the personality so strongly marked in context.

Keywords: Feminine homosexuality. Compulsory heterossexuality. Territory.

\section{INTRODUÇÃO}

Um dos objetivos a que esse trabalho se propõe é conhecer como se dá as interações afetivo-sexuais das mulheres que mantêm relacionamentos com mulheres, somado a isso compreender as relações das mesmas nos espaços de sociabilidade. Em especial, descreverá as negociações realizadas no território da cidade (Serra Talhada) e suas particularidades.

\section{CONTEXTUALIZANDO O TERRITÓRIO}

Na história ocidental moderna, a sexualidade foi aspecto de controle e vigilância, e através de várias instituições (escola, família, as instituições religiosas, mídia, religião) são assimiladas as concepções e comportamentos aceitáveis de como devemos lidar com ela. Nesse contexto, as normas de gênero e sexualidade foram constituídas e compreendidas como verdades absolutas (LOURO, 2008). Diante disso, será apresentada uma breve descrição do contexto que esta pesquisa foi realizada e na sequência o manejo da interlocutoras com o território quanto o exercício da sexualidade dissidente.

Serra Talhada ${ }^{3}$ é uma cidade com 79.232 habitantes e que fica localizada no Sertão do Pajeú, a 416km de distância de Recife (Capital do Estado) e a 350km de Petrolina (divisa do Estado com Bahia). Esse sempre foi um referencial muito importante para que me habituasse com a cidade, já que podia circular facilmente entre dois lugares que me proporcionava bons espaços de sociabilidade e sem a preocupação com as amarras profissionais que exigia residir em Serra Talhada.

${ }^{3}$ De acordo com o último censo do IBGE 


\section{Revista \\ Debates Insubmissos}

Serra Talhada é conhecida por trânsitos facilitados para o acesso ao Ensino Superior, mas também é uma referência quanto espaços de sociabilidade juvenil, principalmente homoeróticos para os dissidentes de cidades circunvizinhas. Além disso, possui um trânsito facilitado para habitantes de outros Estados, como a Paraíba (distância de 55,2 km) e Ceará $(289 \mathrm{~km})$.

Com relação ao Ensino Superior, são ofertadas vagas para cursos de diversas áreas na Universidade Federal Rural de Pernambuco (UFRPE), Universidade de Pernambuco (UPE), Instituto Federal (IF- Sertão - PE), Autarquia de Ensino Superior de Serra Talhada (AESET), além de uma ampla gama de faculdades particulares. Inclusive, muitas pessoas se deslocam de cidades circunvizinhas todos os dias para conseguir cursar o Ensino Superior. Com isso, a cidade se tornou um polo educacional para a Região.

Serra Talhada está localizado no Sertão Pernambucano, mais especificamente no Sertão do Pajeú. E com isso garante as especificações, características e tradições do Sertão, onde o Sertanejo é visto como valente, forte e que precisa de destreza para lidar com as impossibilidades diante da estiagem. Entretanto, por mais que as cidades sertanejas tenham avançado em sua urbanização permanece o simbolismo e os traquejos de um contexto rural, com forte religiosidade e relações de poder.

Quanto às representações sobre o sertanejo, são rotineiramente associadas à dependência e subserviência ao sistema coronelista, porém também ligada à valentia para almejar a sobrevivência diante de tantas impossibilidades naturais (seca). No imaginário social, são lugares percebidos e pelo tradicionalismo e patriarcado.

Essa presença masculina e a autoridade que lhe é atribuída é representada fortemente pela história do Cangaceiro Lampião. Registrado com o nome Virgulino Ferreira da Silva e nascido em Serra Talhada, teve a sua história marcada por fortes relações de poder, que se resumiam em vinganças em busca de honra.

Lampião, que é visto de modo ambivalente (herói ou bandido) pelos habitantes da Cidade, mesmo assim permanece sendo homenageado em vários locais do município que têm referência ao cangaço e a sua biografia. São conhecidos nacionalmente por suas histórias de 


\section{Revista \\ Debates Insubmissos}

violência e vingança que em busca de honra se perpetuou muitas mortes. Assim, perpetuou-se a representação da violência como uma forma de afirmação de poder.

Sobre as mulheres e o cangaço pouco se fala. O que é colocado é referente a sua entrada para o cangaço, muitas foram sequestradas, e a questão da maternidade, pois não podiam permanecer com seus filhos, destinando seus cuidados a familiares e amigos.

Poder de decidir, poder de decidir pela vida ou morte do outro, sobre os corpos das mulheres. Aonde o bando chegava não havia muitas opções para aqueles que ali residiam a não ser travar guerras para manter seus desejos ou ceder aos ensejos do bando. E ao que a literatura remota que se iniciou a briga de famílias vizinhas se tornou uma disputa de poder marcada por muito sangue que ficou conhecido nacionalmente. Além da marca da violência, o Cangaço faz referências a várias formas de cultura e arte, como a dança/ritmo Xaxado e os cordéis.

Com todos esses simbolismos, à medida que fui me instalando, pude conhecer pessoas, seus costumes, a rotina da cidade, assim como a honra e desafetos de seus habitantes. Nessa cidade alguns costumes nunca perdem seu sentido. Um dos maiores eventos festivos da cidade é a Festa de Nossa Senhora da Penha, conhecida também como a Festa de Setembro, que se dá em comemoração ao aniversário da Padroeira da Cidade (Nossa Senhora da Penha) e é o período em que muitos dos que estão residindo fora da cidade (por motivos de trabalho ou estudos) retornam para encontrar e festejar com seus familiares. A cidade fica fervorosa e se desenvolve um momento de saudosismo para aqueles que já puderam participar nos anos anteriores e continua sendo perpetuado pelos mais jovens que ali nasceram.

A cidade ainda mantém algumas festividades como as Pegas de boi e corrida de jegue eventos festivos tradicionais são organizados como forma de movimentar a economia local eventos que são organizados em locais na área rural da cidade. Nesses eventos há disputas esportivas, onde desempenham as atividades com o uso de animais (boi e jegue) e sempre regado ao som do forró ou música sertaneja, como também de uso de bebidas alcoólicas. Cultura como forma de lazer. Eventos em outras cidades próximas também são frequentadas pelos moradores de Serra Talhada, como a festa dos estudantes em Triunfo, a festa de Nazaré do Pico, entre outras. 


\section{Revista \\ Debates Insubmissos}

Serra Talhada foi também escolhida, apesar de ser maior do que as suas circunvizinhas, devido a facilidade de acesso as interlocutoras, assim como de deslocamento para a pesquisadora. Por também ter a ciência que muitos dos jovens dessas cidades menores se deslocam para os espaços de sociabilidade em Serra Talhada, devido não ter muitas possibilidades em suas cidades de origem. Além disso, pela repercussão que a história de Lampião e do cangaço tem na cidade.

Com o intuito de obter mais informações sobre o território e como se dava as negociações das mulheres que se relacionam afetivo-sexualmente com mulheres foi realizada observação em alguns dos espaços informados pelas interlocutoras nas entrevistas. Vale salientar que essa observação não objetiva e não é totalmente isenta, já que esses espaços são também ocupados por mim, mesmo que não com a mesma frequência que destacaram as entrevistadas. A concha acústica (Marco Zero da Cidade) e o estabelecimento Espaço Concha's foram destacados como importantes espaços de socialidade homoerótica.

A concha acústica de Serra Talhada fica localizada no Centro da cidade e foi o ponto de partida para a estruturação do Município. Neste local, tem poucas residências habitadas principalmente por idosos, e, como também acontece com os estabelecimentos, coladas umas nas outras. Geralmente, nos fins de tarde e finais de semana, é possível encontrar crianças brincando com seus pais na frente da igreja, assim como idosos sentados em frente à suas casas. Já na parte noturna, outro público habita o espaço. Pessoas mais jovens ocupam a praça e reinventam o ambiente.

Quando essa pesquisa se iniciou havia pouco investimento na ocupação da Praça da Concha e até os estabelecimentos comerciais que ali se instalavam não perduravam por muito tempo, sejam eles voltados para o público LGBTQ+ ou não. A praça que é considerada um cartão postal da cidade, permanecia apenas com a sede da Banda Filarmônica Vilabelense, pois em 2016 a Casa do artesão havia fechado suas portas.

No ano 2016, O espaço Concha's ${ }^{4}$ é instituído, onde anteriormente era instalada a Casa do artesão

\footnotetext{
${ }^{4}$ Que inicialmente foi inaugurado com o nome Concha's Rock Bar.
} 
e tanto a praça quanto o estabelecimento começam a movimentar aquela localidade. Pude perceber que aqueles espaços, que também eram espaços de sociabilidade LGBTQ+, são abertos e acessíveis, entretanto é nítido como também são percebidos como associados a marginalidade, ilegalidade e para uso de drogas ilícitas.

Por volta de agosto e setembro de 2017 , a população da cidade cobra as autoridades públicas no sentido que ocupassem aquele espaço, assim como encontrassem meios de proteger o que é o "cartão postal da cidade" para que não se instituísse como espaço para uso de drogas e vulnerabilidade, a Prefeitura retorna com o calendário de atividades culturais no local.

Diante disso, durante o processo de construção dessa dissertação busquei estar mais atenta as percepções que os moradores da cidade tinham com relação a esses espaços de sociabilidade LGBTQ+ (Praça da Concha e ao estabelecimento Espaço Concha's) e era muito constante que pessoas heterossexuais expressavam uma preocupação que seus filhos não tivessem frequentando tais locais, já que ouvia-se falar como um lugar onde o uso de drogas é facilitado. Algumas vezes me atrevia a questionar se já haviam frequentado os espaços e negavam essa possibilidade.

Para os jovens, principalmente para os dissidentes de gênero e sexualidade, o Bar Espaço Concha's se tornou um símbolo de resistência, em que, no coração da cidade, é possível ter um lugar que possam se vestir do modo que acham conveniente e expressar seus afetos. $\mathrm{O}$ Concha's é um lugar de resistência, que tenta se manter de modo acolhedor as diversas possibilidades de existência, mas que também sofre com as mesmas dificuldades dos que ali frequentam, pois assim como o seu público, ainda não obtêm muita autonomia financeira. Para mim, era um espaço de representatividade e que tinha sua importância. Mas hoje percebo como um lugar de muito acolhimento e que passou a ter um sentido simbólico que foi constituído durante a construção da pesquisa.

E é por esses motivos, que se faz necessário compreender os atravessamentos da homossexualidade feminina no processo de subjetivação e a relação com aspectos da territorialidade. 


\section{CAMINHOS METODOLÓGICOS QUE CONSTITUÍRAM ESSA PESQUISA}

A presente pesquisa destinou-se a investigar as estratégias de resistência à heterossexualidade compulsória utilizada por mulheres que mantêm relações afetivo-sexuais com mulheres na cidade de Serra Talhada. Especificamente, delinear as concepções atribuídas à sexualidade e à homossexualidade feminina nas relações sociais por mulheres que mantêm relações afetivo-sexuais com mulheres; descrever como se configuram as interações afetivosexuais entre mulheres na cidade; identificar os mecanismos de regulação da sexualidade e analisar as estratégias de resistência à norma utilizada pelas mulheres.

Diante disso, acessou-se as narrativas de mulheres que mantêm relações afetivo-sexuais com mulheres, através do Método Biográfico, pois assim, foi possível reconstruir acontecimentos sociais a partir da perspectiva da história das informantes (BUENO, 2002), bem como conhecer as negociações que elas estabelecem com o território. Para alcançar os objetivos a que essa pesquisa se propôs, o trabalho de campo foi realizado na cidade de Serra Talhada e deu-se por meio de entrevistas. Nestas, utilizou-se um roteiro com enfoque biográfico, que objetivou a reconstituição da história de vida afetivo-sexual das interlocutoras (RIOS, 2004).

Com relação à seleção das participantes, a pesquisa teve como critérios de inclusão mulheres com experiências afetivo-sexuais com mulheres, com idade entre 18 e 30 anos que residam em Serra Talhada, pois é importante considerar os aspectos geracionais e suas múltiplas interfaces. Assim, quanto aos critérios de exclusão, não foram incluídas mulheres com idade inferior a 18 anos e acima de 30 anos e que não residam em Serra Talhada.

Inicialmente, foi realizado contato com mulheres que mantêm relações afetivo-sexuais com mulheres dos vínculos de proximidade da pesquisadora. Para selecionar as participantes foi utilizada a amostragem por bola de neve (Snowball Sampling) (VINUTO, 2014), tendo em vista que a pesquisa aconteceu em um município onde a temática ainda permanece na invisibilidade, facilitando o encontro da pesquisadora com as interlocutoras privilegiadas.

Em relação à quantidade de informantes, foram realizadas entrevistas com 9 (nove) mulheres. E foi utilizada a ferramenta de amostragem por saturação, assim, com essa quantidade 


\section{Revista \\ Debates Insubmissos}

de interlocutoras, foi possível responder aos objetivos da pesquisa (FONTANELLA; RICAS; TURATO, 2008).

Também foi utilizada a observação participante com intuito de descrever como é Serra Talhada como local de pesquisa, o que auxiliou com a contextualização das narrativas apresentadas. Como afirma Uwe Flick (2004), através desse método é facilitado aos pesquisadores acessar os espaços e pessoas que podem contribuir com a pesquisa, assim como acessar redes de sociabilidade de mulheres que mantêm relações afetivo-sexuais com mulheres anteriormente não acessadas. Os dados produzidos a partir da observação foram registrados no diário de campo e analisados conjuntamente com as entrevistas das interlocutoras.

Após a coleta de dados, foi realizada a transcrição das entrevistas e análise dos dados. Com relação à metodologia de análise de dados, foi realizada a análise temática dos dados, que, como descreve Gibbs (2009), parte da leitura do material e em seguida agrupamento das ideias temáticas e questões estruturais que aparecem nas narrativas.

Esta pesquisa foi realizada de acordo com as normas da Resolução No 466/12 e n n 510/16 do Conselho Nacional de Saúde. O projeto foi encaminhado ao Comitê de Ética em Pesquisa em Seres Humanos da UFPE.

\section{ANÁLISE}

\subsection{As interações afetivo-sexuais}

As interlocutoras descreveram alguns aspectos que contribuem para facilitar as interações afetivo-sexuais entre mulheres, como: os amigos em comum, aplicativos de namoro, redes sociais, entre outros. Cabe destacar também o "rebuceteio" que é bastante conhecido pelas lésbicas e se refere a uma possibilidade de circuito de relacionamento entre as mulheres, como vai ser melhor discutido posteriormente.

O fator mais destacado pelas interlocutoras foram os amigos em comum. Funcionando como fonte de contatos entre as mulheres, colocam que os amigos fazem a aproximação através das afinidades, relatam sobre a abertura para se relacionar com mulheres, tomando como 
referencial aspectos em comum, na medida que muitas vezes os laços se estreitam entre elas. Os amigos em comum descrevem que as mesmas têm afinidades em comum e direcionam, como descrito abaixo:

[...] meio que assim... o grupo de amigos chegam: 'oh, aquela menina tá interessada em você, ou então tem uma amiga minha 'que curte', você quer que eu ajeite, apresente e tudo mais'. Ai já fica mais fácil... porque tem amigos que conhece outras pessoas e acabam apresentando e conhecendo mais e mais. (MUCUNÃ, 19 anos).

Além dessa estratégia, as interlocutoras fazem uso do aplicativo Tinder. Que se destina a facilitar encontros entre pessoas que objetivam relações afetivo-sexuais. Essa ferramenta faz a seleção de perfis que encaixem nas escolhas dos participantes, isso considerando o território e a distância em quilometragem que as pessoas estão dispostas a percorrer para conhecer alguém. A partir das fotos e informações prestadas pelos usuários é possível sinalizar interesse ou não. Caso as duas partes demonstrem interesse gera um "Macth" (combinação de interesse), que abre possibilidade para uma conversa por mensagens privadas e maior aproximação.

As entrevistadas descrevem que, por mais que o Tinder seja uma ferramenta muito utilizada por homossexuais e heterossexuais, não temem expor neste a busca de relacionamentos com mulheres, mesmo quando não são assumidas quanto a sexualidade para a família. E que por mais que não seja a primeira fonte de interações afetivo-sexuais, é um meio bastante utilizado. Inclusive um dos casais entrevistados na pesquisa se conheceu através do aplicativo.

Ainda se falando sobre o uso da internet e suas ferramentas, os aplicativos de redes sociais (Facebook e Instagram) são bastante utilizados para a paquera e iniciar as interações afetivo-sexuais. Algumas entrevistadas descrevem que a partir dos contatos dos amigos, descobrem quando uma mulher se relaciona com mulheres e aproveitam as redes sociais para afinar o contato. Através de curtidas nas fotos, interação através das histórias, até estreitar os laços.

Por exemplo, alguém vê um Instagram, aí diz: opa, tudo bom? Ai fica aquela conversinha ai depois marca de sair, ai marca para comer alguma coisa, um lanche, ai sempre a pessoa tá na concha com a pessoa, ou a gente sai para casa de uma ou da outra, geralmente eu sempre vou para casa da pessoa nunca vão para a minha, porque como tem muita gente na minha casa eu nem levo, nem passa. (RABO-DE-RAPOSA, 18 anos). 


\section{Revista \\ Debates Insubmissos}

De acordo com Richard Miskolci (2009, p. 65), as plataformas de socialização é uma maneira de "formar redes relacionais sem necessariamente frequentar boates ou bares gays". Além disso, isso aconteceria de modo protegido, manobrando a vigilância e evitando a exposição para as que mantêm a sexualidade dissidente em segredo, assim como retaliações sociais.

Guacira Louro (2008) descreve que estamos constantemente sofrendo transformações na história, na cultura e que isso interfere nos modos de ser e viver. Isso repercute nas quebras de impedimentos com relação as normativas de gênero e sexualidade, como também abriu possibilidade para os relacionarmos afetivos através dos meios virtuais. Questiono se essas interações através das redes sociais seria um aspecto geracional, já que há uma tendência na atualidade a interagir através das mídias sociais. Ou se isso se deve a um traço mais intimista para fazer investidas amorosas. Acredito que a interação de tais aspectos seja a resposta, já que através das trocas seria possível anonimato, mas também espelhamento/reconhecimento.

Outro aspecto apresentado pela rede de colaboradoras da pesquisa foi o Rebuceteio, um fenômeno que sempre está presente nas interações afetivo-sexuais entre mulheres. De origem desconhecida, mas conhecida por todas; significa basicamente a rede de relações entre lésbicas, na qual as relações afetivas e/ou sexuais acontecem entre lésbicas que pertencem ao mesmo grupo, como Quipá (19 anos) descreve:

Todo mundo fica com todo mundo. Vai todo mundo para uma festa, eu, você e Thor ${ }^{5}$... aí hoje eu fico com você, aí amanhã tem outra festa aí você vai e fica com Thor, aí depois de amanhã tem outra e aí eu fico com Thor também. Porque simplesmente a gente é amigas e achou Thor interessante, você beijou, disse que o beijo dele é bom, eu vou lá e vou querer beijar também.

Esse modo de interação afetivo-sexual entre lésbicas, é descrito no seriado "The L Word", que representa um quadro com os relacionamentos vivenciados na trama entre as personagens, e que reflete os relacionamentos lésbicos no cotidiano, como pode ser apresentado a seguir:

${ }^{5}$ Nome fictício 


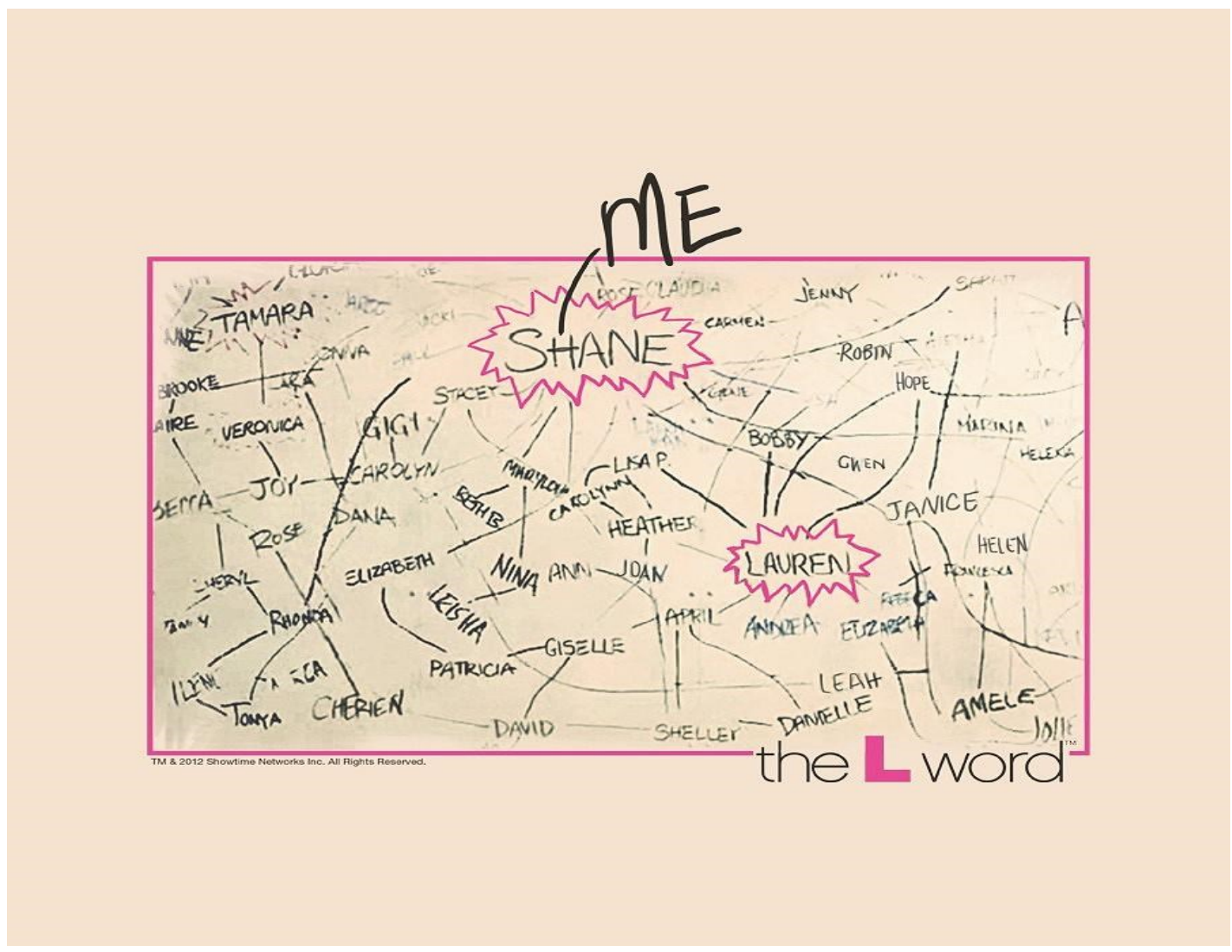

Vale salientar que Rebuceteio também ocorre em cidades maiores, mas parece ganhar outro sentido em cidades menores. Pois, como as interlocutoras descrevem, passa a sensação de ter que repetir de 'figurinhas', já que não teria tantas opções assim. Algumas interlocutoras colocam este fenômeno com certo desconforto, outras brincam com a situação. E acrescentam que a tendência dos ciclos do rebuceteio é agregar mais participantes, já que observam que as meninas estão investindo pouco em namoro e buscando permanecer com relacionamentos mais casuais.

A busca por relacionamentos mais casuais é um contrapondo nas vivências quanto aos relacionamentos lésbicos. No imaginário coletivo é comumente colocado que as mulheres lésbicas investem mais em relacionamentos mais fechados e duradouros, diferentemente dos gays. E que isso aconteceria justamente pelas meninas serem incentivadas a investir no amor romântico desde a infância. $\mathrm{O}$ que não quer dizer que elas se restrinjam a se relacionar afetivamente em detrimento de sexualmente. Porém, como Louro (2009) aponta, as mulheres 
são ensinadas a investir menos na esfera sexual do que os homens e se mostrar aberta a debater tais assuntos ainda é tabu e demanda um processo de desconstrução do que foi nos ensinado. Peso das questões de gênero que possibilitam aos homens uma vida sexual ativa e as mulheres uma vida regrada.

E por mais que o rebuceteio seja um assunto recorrente e cotidiano, não foi encontrado pesquisas sobre tal fenômeno bastante conhecido entre as mulheres que se relacionam com mulheres. Além disso, é um aspecto importante a ser discutido por existir uma roda de solidariedade que sustenta o rebuceteio.

\subsection{Espaços de sociabilidade}

Para iniciar falando desse tópico, será apresentada a fala de Angico, que retrata o uso dos espaços de Serra Talhada pela comunidade "alternativa":

[...] no início dos anos 2000, eu acho que até historicamente o grande espaço de lazer sempre foi a praça da (igreja) matriz, Nossa Senhora da Penha ${ }^{6}$, mas aí no início dos anos 90 e início dos anos 2000 uma outra comunidade jovem começa a tomar de conta daquele espaço. Não é mais só o branco burguês conservador católico que sai da missa e vai sentar na praça com a namorada, ali tem gente que vai para fumar um cigarro, que vai fumar maconha, tem gente que vai para tomar cachaça, tem gente que vai para transar, sei lá, enfim... tinha de tudo na praça nesse período, todo tipo de jovem. Os jovens serra talhadense tavam muito mais antenados e globalizados do que o jovem interiorano da época do meu pai, do seu pai... enfim. E ai basicamente era aquele espaço e quando começou a criar outros espaços de lazer para essa população LGBT era promovida por ela própria, era algumas pessoas que estavam um pouco mais velhas, que tinha um pouco mais de consciência política ou queria fazer algo diferente que fazia uma festa em uma pizzaria ${ }^{7}$, em algum clube da cidade, é.. que reunia a galera em algum lugar, e queria promover alguma coisa diferente, depois de um bom tempo começaram a surgir as paradas da diversidade, que sempre tinha o nome de parada gay, até hoje não é chamado por parada da diversidade ou parada LGBT, é parada gay, e lésbica, bissexual, transexual, travesti e queer esse resto da galera nunca existiu na cidade. Em Serra sempre teve representações muito claras dessas pessoas, de todas essas classes, e... era praticamente isso. Hoje em dia tá mais diversificado, porque eu acho que essa população se sente mais à vontade de ocupar espaços historicamente héteros, de ir para bares que a gente sabe que é historicamente hétero....

\footnotetext{
${ }^{6}$ Praça Doutor Sérgio Magalhães, praça central da cidade e que fica a 500m da Praça da Concha Acústica de Serra Talhada

${ }^{7}$ Ainda acontece muitas festas em pizzarias que possui espaço para festas, quadras de esportes e clubes, onde o público frequentado é predominantemente LGBT. Esses espaços também são utilizados para calouradas proporcionadas pelos estudantes das instituições de ensino.
} 


\section{Revista \\ Debates Insubmissos}

mas de vez ou outra a gente encontra um grupinho lá no meio, até nas festas também. Mas eu acho que quase como todo interior não tem incentivo público e quando tem alguma atividade desse tipo é promovida por nós mesmos, de forma bem informal e enfim é isso... e agora a gente tem a concha né? Que é o lugar de tudo e de todo mundo. (ANGICO, 26 anos).

O que foi descrito por essa interlocutora também é apresentado pelas demais. A Concha é colocada como o principal ponto de sociabilidade LGBT, já os outros espaços (bares, restaurantes e festas) são descritos como "espaços héteros", onde nem todas as dissidentes se sentem abertas a possibilidade de demonstração de carinho, por mais que frequentem com suas parceiras.

A concha se torna, em especial, lugar de encontro do público LGBT, possibilitando encontros e trocas de afetos, como demonstra a fala abaixo:

Quando a gente tá andando na rua a gente não anda de mão dada, só anda perto mesmo... não anda de mãos dadas, não se toca, não se beija, a não ser quando a gente vai para a concha que é um lugar que todo mundo tá lá, que é um lugar que ninguém liga e tal... a gente se sente mais à vontade lá. Para pegar na mão e beijar. (XIQUEXIQUE, 19 anos).

Nessa fala, é possível perceber também uma duplicidade nos modos de se posicionar, ora precisam negociar com as normativas heterossexuais e ora é possível exercer livremente a sexualidade. Isso varia de acordo com o local em que a mulher lésbica esteja inserida. Esses lugares que acolhem as variadas formas de afetos, facilitam a expansão dos vínculos de amizade e suporte social.

Outro lugar de sociabilidade LGBTQI é o bar Espaço Concha's. Além do bar ser um espaço de sociabilidade, onde os jovens podem ir para dançar, curtir e conhecer pessoas novas. É também um espaço carregado de significados afetivos por parte desse público por acolher e lutar pelas demandas do público dissidente. Com certa frequência, o espaço é utilizado como ponto de discussões e debates sobre pautas ligadas aos Direitos Humanos, como também é caracterizado com um espaço que combate qualquer tipo de opressão e discriminação. Contudo, algumas jovens também se utilizam de outros espaços para essa troca de afetos.

Como pontuado por James Green (2000), nos anos 50 era presente a utilização dos banheiros públicos, dentre outros, como ponto de encontro de homossexuais masculinos. E coloca que devido à pouca ou nenhuma autonomia financeira precisavam reinventar formas de 


\section{Revista \\ Debates Insubmissos}

se encontrar para trocas afetivas e/ou sexuais. As interlocutoras reafirmaram o uso desses espaços, pois como muitas vezes "rolava um clima" em lugares de circulação comum recorriam a banheiros públicos como uma forma de trocar beijos e carícias e não serem percebidas. Como exemplificado abaixo:

[...] a gente ficou de férias do primeiro ano, na casa de uma amiga da gente, viramos a noite bebendo, fui no banheiro e ai vieram três... amiga, abre a porta, não sei o que... sim, eu tô aqui... não sei o que, abre a porta, a gente tá apertada... tá bom... quando cada uma terminou, uma vira para mim e fala: 'beija a gente' e a pessoa beba, a pessoa, eu mesmo só sei dar risada, ai eu disse: 'como assim, menina?' Oxe... não, é sério, beija a gente! A gente quer saber como é beijar uma menina, não sei o que... você que já beija menina... eu beijo, mas e vocês? Se beijem e vão saber como é que é, eu não vou beijar vocês, até porque não tinha ne? Conexão nenhuma, era só amizade, aí ficaram nisso... beija a gente, beija a gente, e eu não... e sai.Vem bebida, vem bebida, vai hora... e essas meninas 'beija a gente, você vai ficar com a gente', ai eu: 'o que é que eu tô fazendo aqui que não tô beijando essas meninas?', ai eu fui beijar essas meninas, ai eu beijei a primeira, a segunda e a terceira....ai depois 'ah, vamos dá beijo triplo, depois ah, vamos as 4'... e ai virou uma bagunça já ne? Risos. Mas foi divertido. (MALVA, 20 anos).

ela chegou assim e vamos ali comigo, eu senti na hora, é agora... eu: 'porra, fudeu... eu tô comendo salgadinho de cebola, não tem problema?' Ela: 'não, tem não...' (risos) eu avisei antes porque eu fiquei morta de vergonha, aí eu peguei... ela me puxou para dentro do banheiro aí a gente se beijou, aí ela beijou e disse assim: 'tava comendo salgadinho de cebola?' Eu: 'eu disse a você, coma um por favor para eu não me sentir tão constrangida' (risos) aí ela comeu um pouco aí a gente comeu e pronto, foi isso. E se beijamos. E depois saímos e fiquei tipo... olha não conseguia nem disfarçar a cara, sei que eu consegui passar o resto da semana rindo assim, oh (fazendo uma cara de felicidade, demonstrando o maior sorriso que poderia fazer). (RABO-DERAPOSA, 18 anos).

Acrescentam que foram em espaços assim que obtinham trocas no início da juventude até pela impossibilidade de ambientes seguros. E mesmo que não fossem utilizados com muita frequência, era uma alternativa de vivenciar a sexualidade sem exposição. Ocupam esses espaços, em sua maioria, mulheres mais jovens já que as dissidentes com mais idade, estão envolvidas em relacionamentos mais estáveis e circulam em espaços mais privados ou tem maior poder aquisitivo, o que possibilita outras opções de sociabilidade.

O que pretendo problematizar aqui é que as interlocutoras colocam que estão constantemente negociando com o território e fazendo o jogo de luz e sombra. E assim teriam baixa visibilidade em espaços mais tradicionais e maior visibilidade onde as relações afetivas/sexuais entre mulheres, em especial, são possíveis. 
Não podemos deixar de destacar quanto esse território é polarizado quanto as suas repercussões. Com a expansão das mídias sociais, as notícias das cidades são rotineiramente divulgadas através de blogs, é a maneira de exercer a imprensa local em cidades menores. Assim, tanto a Concha quanto o referido bar se tornam alvos constantes de críticas e denúncias.

Porque o pessoal se conhece, é bem tranquilo, e sempre quando você vai, o pessoal vai com os amigos dá um rolezinho lá, ai é isso, é mais fechado, é menos acessível a todo mundo, e fora que o pessoal daqui bota uma fama na concha dizendo que só tem maconheiro e drogado, mas não pow... tem em todo canto[...] (RABO-DE-RAPOSA, 18 anos).

Por conta da repercussão, esses locais se tornam alvo de ações policiais que se justificam no uso de drogas ilícitas.

Tem uso de drogas em todas as praças da cidade, mas sempre teve uma polarização entre essas duas praças, porque a praça Sérgio Magalhães é lugar do branco burguês que desce da missa e vai curtir aquele lugar de fala, que foi uma praça muito importante da cidade, que a matriz é onde a população rica e branca frequenta e expressa sua fé, enquanto a concha era um dos poços de escravos da cidade, e onde a igreja foi construída por escravos, que recentemente foi legitimada como Nossa Senhora do Rosário dos Pretos, e é um lugar marginalizado... por... isso.. assim... por natureza. E a população que é vista como marginal, que ocupa esse lugar é para tentar se empoderar, e perder a história dele é marginalizar duas vezes mais e escantear enfim [...]" (ANGICO, 26 anos).

Desse modo, surge o seguinte questionamento: já que sabemos do consumo de drogas em outras partes da cidade, porque o espaço se tornou alvo constante de controle e vigilância policial? Qual realmente é o incômodo produzido pela ocupação daquele espaço? Até que ponto a intervenção policial funciona como modo de dispersão da população LGBTQI e enfraquecimento da resistência?

\subsection{Negociando com a cidade e ocupando territórios}

Um dos destaques desse trabalho é discutir sobre as dissidências fora das grandes cidades, e não foi uma tarefa fácil. Como apresentado mais acima, as mulheres buscam estratégias de interações afetivo-sexuais que garantam certa proteção dos ataques moralistas. Quanto aos espaços de sociabilidade, restringem as demonstrações de afetos aos guetos homossexuais. Mesmo quando assumidas, ainda precisam estar em constantes negociações com 


\section{Revista \\ Debates Insubmissos}

as construções que sustentam a heterossexualidade compulsória e as instituições que a perpetuam.

Isso, levou muitas das mulheres que foram contatadas para a pesquisa a se mostrarem receosas quando apresentado o objetivo desta. Ademais, negaram qualquer envolvimento afetivo-sexual com mulheres como forma de evitar falar sobre o assunto... outras, até afirmaram algum envolvimento com mulheres, mas tinham receio de que fossem expostas ou descobertas, o que é compreensível. Afinal, quantos medos estavam ali entrelaçados, quantas negociações não são feitas todos os dias para manter a sua "segurança"?

Essa exposição provocada pelo território se mostrou como uma dificuldade para alcançar mais interlocutoras, mas reflete também as tensões que precisam ser negociadas dentro desse contexto. E por mais que Serra Talhada não seja uma das menores cidades da Região, o forte diálogo e trânsito com as outras cidades, assim como as tensões provocadas pela pessoalidade das relações, nos fazem sentir ameaçadas e vigiadas.

Com relação a vigilância, algum dos aspectos que chamam a atenção de familiares e vizinhos é a performance apresentada pelas mulheres. Caso apresentem uma performance mais próxima a masculina a vigilância se acentua.

E nós lésbicas que não performamos essa feminilidade desejada... a gente é muito comparada a homem, seja sutilmente, seja com o olhar, mas uma hora ou outra rola. E quem é lésbica que performa feminilidade sempre tem aqueles comentários machistas "que nem parece", que é hipersexualizada, que isso também acontece, não é o meu caso, mas várias e várias amigas minhas são alvos de "mas tu é tão bonita e tu é lésbica..", "ah, é lésbica porque não achou um homem que te fizesse feliz", graças a Deus que não achou, se ela é lésbica é porque achou alguém que a fizesse feliz (risos).... de outro jeito ne?! É um falocentrismo tão voraz, que é muito sustentado pelo homem. (ANGICO, 26 anos).

Ainda sobre as possibilidades de performance, Xique-Xique retrata:

Primeiro, se você... mesmo que você não tenha nenhum relacionamento, mas veem você andando com uma menina que se veste de forma masculina e tudo mais ai já causa olhares, o pessoal... acho que é porque tem muito aquela questão, de tradicionalismo aqui... eles não aceitam ou nunca viu, não sei. (XIQUE-XIQUE, 19 anos).

Esse fator interfere nas interações afetivo-sexuais, já que a interlocutora colocou que por diversas vezes sua genitora exige afastamento quando suas amigas apresentam performance masculinizada por compreender que isso as fazem lésbicas. Lívia Toledo (2008) problematiza 


\section{Revista \\ Debates Insubmissos}

o estereótipo que "lésbicas são masculinizadas" apontando que as construções sociais direcionam o que é masculino e feminino, e contrapõe colocando que as características de gênero estão presentes em todas as pessoas, tanto femininas quanto masculinas. Então, apresentar uma performance mais próxima ao que é considerado masculino não as fazem lésbicas.

As colaboradoras da pesquisa declararam que percebem a pressão por adequamento, mesmo de pessoas que não tem proximidade, através dos olhares, quando apresentam uma performance mais próxima ao considerado como masculino. Acrescentam que concomitante a isto, são cobradas quanto aos papéis sexuais femininos, como demostra o trecho abaixo:

Se Lampião era o cabra macho, Maria bonita que era também a figura que deve ser seguida, a mulher que obedecia seu homem entre muitas aspas, mas que tava ali ao lado dele. E ai ser mulher lésbica no sertão Pernambucano, bichaaa... é complicado porque as vezes querem igualar a gente a que quer ser um homem, e ai se você não performa feminilidade você é homem, quer ser homem, ai você quer ser tratada como homem, ou ser tratada de uma forma... te subjugar até você virar mulher entre aspas e performar essa feminilidade que é aceita, e eu não performo tanto assim... apesar de não me achar muito masculinizada, só as vezes enfim [...] (ANGICO, 26 anos).

Como já foi citado anteriormente, estamos em terra de Lampião, e essa figura masculina prevalece entre as histórias da cidade, assim como as representações em torno dos personagens se expandem para os habitantes do município, principalmente no que se refere aos padrões de gênero. O homem Lampião, aquele que impera masculinidade, autoridade e poder; a mulher Maria Bonita, que por mais que tenha rompido algumas normas impostas pela sociedade, permanece a sombra da figura masculina.

Além disso, as terras do Nordeste Brasileiro, principalmente seus interiores, carregam tradições de coronelismo e forte patriarcado. Foi muito vigente o poder de decisão e autonomia restringir-se apenas aos homens, estes que iriam definir até sobre o uso do corpo feminino. Consequentemente, as mulheres que almejam esse poder de decidir para si, são percebidas como alguém que deseja “ser homem”. É essa lógica que sustenta também a violência contra as lésbicas, onde tais práticas objetivam adequamento das mesmas, seja no quesito gênero ou sexualidade.

Ainda com relação a definição quanto as construções sociais de homem e de mulher, Flor-de-cera apresenta: 


\section{Revista \\ Debates Insubmissos}

Tem muito aquela construção de que é homem, mulher, tem que ser assim, 'ah, isso é coisa de viado', eles realmente falam assim... e eu acho que para as mulheres é uma questão forte, porque quando a gente se posiciona que a gente não se submete, aos homens nem mesmo na questão sexual porque para as outras mulheres, elas se desvinculam dos homens em outras relações, mas elas ainda continuam se relacionando com eles. Acho que ser lésbica em uma cidade assim que tem muito a masculinidade, é muito imposta e as mulheres se submetem a ela, é uma afronta mesmo. Você diz: 'não, eu não vou me relacionar com homens', e é uma coisa muito que... eu acho que as vezes pode soar como um insulto para a sociedade. (FLOR-DECERA, 18 anos)

$\mathrm{Na}$ terra onde o homem tem o poder, querer se posicionar contra as normas é considerado um insulto. A subversão é algo que vai ser constantemente vista como ameaça.

Ainda pensando o que é colocado como autorizado para as mulheres ou não, Angico traz as dificuldades quanto a restrição de espaços para as mulheres, em que foi constantemente estimulada a ocupar espaços domésticos. Vale salientar que esses aspectos não são apenas direcionados para as mulheres que contrapõe a norma hegemônica da sexualidade, mas se expande para todas em geral.

Na adolescência, até uns 17, 18 anos, era bem mais enfático, de sempre eu sair de casa com os meus amigos e a vida boemia da comunidade, da população LGBT de Serra Talhada é bem intensa e marginal, mas é intensa. E eu queria viver aquilo, mas pelo fato de ser mulher e viver numa família extremamente machista a ponto de não ser LGBTfóbica, mas machista é muito e ai eu não podia fazer certas coisas, não podia chegar em tal horário, não podia sair sozinha e fazia tudo isso a rebelia mesmo, sempre com muito embate, com muito mal estar dentro de casa, mas acontecia. (ANGICO, 28 anos).

Destinar a vida ao núcleo familiar, assim como apresentar uma sexualidade recatada é a imagem positivada da mulher, imagem essa que é perpetuada. Porém, a mulher que nega ser cautelosa e submissa é constantemente direcionada para ajustamento, poder esse geralmente exercido pelas figuras maternas da família, que são responsabilizadas pelos cuidados da prole. Assim, a família exercia um controle sob a interlocutora de modo que gerava acentuados conflitos como meio de colocá-la em ordem e objetivando também evitar comentários que pudessem atentar contra a moral do núcleo familiar.

Quanto às negociações com o território Angico coloca que os corpos dissidentes incomodavam nas suas expressões e que a repercussão se dava de modo negativo, mas que os 
Revista

Debates Insubmissos

amigos acabavam exercendo uma função de espelhamento para ressignificar a forma como se percebiam, como demonstra a fala abaixo:

A comunidade, a população homossexual de Serra Talhada sempre se encontra em determinados lugares que acho que com as relações de amizade você se sente seguro, e fora dela era bastante hostil, de poder sair, de poder expressar a sexualidade namorando... e ai meados dos anos 2000 e pouco, que foi quando essa turma foi crescendo, que foi o maior burburinho na cidade, que os emos estão tomando de conta, que só tem viado e sapatão na cidade, foi que foram se aproximando as turmas, tinha muita pegação, tinha muita pegação, todo mundo se pegava com todo mundo, menos eu. (ANGICO, 26 anos).

Malva apresenta também como a pessoalidade é característica nesse território:

E ai, um certo dia a gente tava bebendo de novo, parece que eu não faço outra coisa... uma das meninas que era $\mathrm{Joana}^{8}$, ela tava com uma mão no meu ombro eu tava sentada, ela ergueu minha cabeça e me beijou, na frente de todo mundo no aniversário dela, e eu fiquei tipo...(expressão de chocada) e todo mundo olhando, ninguém disfarçou, eles nem tentaram disfarçar, eles olharam mesmo e ai qual a explicação de tudo isso, Brasil? E aí não tinha o que dizer, eu: "eita, Rayanne9 tá é bêbada" (risos). Amiga, mulher, vai deitar um pouquinho'... (risos). E aí no outro dia, meu amor... 'Malva, a filha de Alberto $^{10}$, sapatão...' era só o que o povo falava, era... aí pronto, saíram o bafafá... dentro da escola era só o que o povo falava. (MALVA, 20 anos)

A colaboradora da pesquisa coloca que em cidades pequenas as pessoas são conhecidas pela árvore genealógica. É sempre referenciada por ser filha de alguém, pois é comum nas cidades pequenas as pessoas se reconhecerem pelas famílias as quais pertencem, assim como as relações constituídas entre uma família e outra. E dessa forma, boa parte da população se (re)conhece nos espaços do território.

Por conta dessa familiaridade, as famílias são cobradas quando um membro realiza alguma transgressão. A fofoca como apresenta Elias Norbert (2000) se caracteriza como um fenômeno dependente, pois se norteará a partir das crenças, normas e relações construídas socialmente naquela localidade. Desse modo, serve como um instrumento para pressionar a família para realizar o adequamento do transgressor, já que a moral da família seria colocada em xeque.

Como nessas localidades as redes de relações são bem próximas, existe uma preocupação exacerbada com a reputação. Desse modo, as pessoas cogitam não realizar

\footnotetext{
${ }^{8}$ Nome Fictício

${ }^{9}$ Nome Fictício

${ }^{10}$ Nome fictício
} 
algumas ações, pois irão "ficar faladas" e envergonhar toda a família. Resumindo, a pessoa indicada na fofoca é o alvo de controle, assim como a fofoca serve de instrumento para sustentar o estigma de alguém que não zela pela sua honra e nem a de sua família, traço de moralidade bem acentuado em cidades menores.

Sabem daquela coisa bem de perceber, mas em momento algum, principalmente meu pai teve "vamos sentar e conversar...", eu sou lésbica, namoro com tal pessoa e tal... nunca teve muito disso, mas meu comportamento e o comportamento da minha irmã e... as histórias, ne? $\mathrm{O}$ que o povo fala na rua, que isso é bem de interior mesmo, sempre rolou essa conversa." (ANGICO, 26 anos).

Malva também retratou sua experiência com relação as fofocas:

Aí começou o falatório, andávamos sempre juntas, nenhuma era flor que se cheire, e aí perceberam que algo mais ali, que a gente não tava mais ficando com os outros meninos, só andavam as mulheres e quando vinha alguém para ficar não queria. Ah, se você dar um fora em um homem, então é porque você é lésbica, na língua deles, sapatão. (MALVA, 20 anos)

Residir em uma cidade pequena é como se houvesse um quase total controle, no qual seus genitores não precisam estar presentes constantemente, pois existem muitas formas de vigiar.

é, porque digamos assim, porque tem muita gente ainda que os pais não sabem, mas tipo... mesmo que todos os amigos saibam... por morarem aqui e terem família aqui não podem saber, ai muitas vezes você vai para casa da pessoa para poder ser mais discreto e ser mais confortável, porque é muito chato tá com alguém e a pessoa ficar... (faz expressão de como estivesse sendo vigiada)... 'não, não... agora não...' isso sabe? E é tanto que por exemplo para se relacionar aqui em Serra, muitas vezes quando uma é assumida e a outra não é, aí é complicação é essa, ou quando um é e o outro não é, ou quando os dois é... mais ou menos assim. Por exemplo, minha primeira namorada não era, eu também não era, mas eu era mais tranquila, na verdade que a gente só ficava quando a gente tava em casa, quando a gente saia pro roles a gente nem pegava na mão direto, morrendo de vergonha, mas morrendo de vontade, ai pronto. Mas ai, quando eu tava com Joana ${ }^{11}$ a gente já era mais de boa só que, por exemplo, é o pai dela não sabia e nem podia saber, porque o pai dela é bem mais bruto, ai lá na faculdade como tinha mais gente que conhecia ela, que ela morava em outra cidade ai ela vinha e voltava todos os dias e no carro tinha pessoas que conhecia a família e tudo, ai na faculdade a gente não tinha tanta liberdade assim, mas salas estão ai para isso. (RABO-DE-RAPOSA, 18 anos)

Desse modo, mesmo em uma cidade que não a sua de residência, Rabo-de-raposa e a namorada ainda não gozavam de liberdade de expressão de sua relação, devido à vigilância a

\footnotetext{
${ }^{11}$ Nome Fictício
} 
que estavam sujeitas por um grupo de sua cidade ultrapassar os muros e também está presente em Serra Talhada.

Diferentemente aconteceu com Mucunã, que ao sair da sua cidade de origem e mudar para Serra Talhada abriu seu campo de possibilidades com relação a trocas afetivo-sexuais, mas, sobretudo ao que se refere ao controle e vigilância.

assim, em partes eu achei melhor... porque minha cidade é menor do que aqui, todo mundo realmente lá se conhece de alguma forma, quando não me conhece, conhece meus pais, não tem para onde ir... e pra mim eu me sentir mais livre aqui mais à vontade aqui do que lá, porque aqui é uma cidade que ninguém me conhece, então não vou ter que ter medo para tá andando de mãos dadas com alguém, só que eu sei respeitar o local que eu tô. Porque muitas pessoas não aceitam e pode ser que eu sofra algum tipo de preconceito num local, então eu prefiro em alguns momentos, e em alguns locais me recantear, ficar na minha. E para mim foi melhor tá aqui do que lá em Jardins ${ }^{12}$ para eu conseguir ser mais eu. (MUCUNÃ, 18 anos)

E continua:

Lá em Jardins quando eu saio com meus amigos, assim dentro da... quando eu saio para alguma balada, lá eu consigo ser a mesma pessoa que sou aqui, mesmo tendo as pessoas ao redor que conhecem enfim e falam e tudo mais... mas eu me comporto normal que eu me comporto quando tô aqui mesmo, quando chego em qualquer lugar... mas assim, no meio da rua, de dia, perto de algum lugar que tenha bem conhecidos do meu pai, ai eu preferi me comportar para não levar nenhum constrangimento a eles. (MUCUNÃ, 18 anos)

Mucunã, assim, possui um policiamento das suas ações, já que algumas demonstrações de afeto poderiam ser percebidas como da ordem do imoral e repercutir na honra da sua família.

Ainda assim, é como se houvesse uma libertação, na qual é possibilitada a vivência. Mas, se antes tinha principalmente o medo de machucar os familiares com a exposição de afetos, hoje por estar em território diferente dos pais, teme a violência alheia. Aquela que desconhece o agressor... fato também apresentado por Flor-de-cera quando traz a intervenção de um desconhecido frente a sua expressão sentimental para com sua namorada.

Eu lembro que a gente nem sequer andava de mãos dadas na rua, uma vez a gente tava passando ali no centro, eu olhei para ela e falei: 'amor, não sei o que, não sei o que'... o homem olhou para mim assim assustado, ele disse: "não, isso não tá acontecendo... isso não é possível.' Entendeu? Realmente é uma surpresa para as pessoas. (FLORDE-CERA, 18 anos).

\footnotetext{
${ }^{12}$ Nome fictício
} 
É importante analisar que os postulados que sustentam a norma hegemônica da sexualidade são repassados implícita ou explicitamente por diversos canais, como por exemplo, mídia e/ou pelas instituições. E a medida que assimilamos vamos tornando-a como referência e naturalizando esse modo de existência, de modo a rejeitar as infinitas possibilidades de exercer a sexualidade.

Ainda no tocante a esse aspecto, Rogério Junqueira (2011, p. 85) pontua que "Quem não se mostrar apto a ser normalizado torna-se digno de repulsa e abjeção, habilitando-se a ocupar um grau inferior ou nulo de humanidade.”. Foi o que apresentou Malva na fala quanto ao posicionamento da proprietária do imóvel que residia:

Primeiro ela começou com tipo vagabunda, ordinária... aí depois ela inventou coisas, que aí eu acho que foi a menina (vizinha) que ela falou: 'você tá fazendo da minha casa um cabaré'. E ai tipo, era eu, minha namorada e os meus livros porque eu não conhecia tantas pessoas, eu não conhecia quase ninguém, quase ninguém andava lá e casa, o tempo que eu tinha fora da faculdade eu queria passar com ela, e era eu e ela o tempo todo, eu não tinha som, eu não tinha televisão, eu não tinha nada, eu tinha um fogão, uma geladeira e um colchão, nem guarda-roupa eu tinha, então que cabaré eu ia fazer nessa casa? E aí ela falou várias e várias coisas assim. (MALVA, 20 anos)

Tenta atingir a moralidade dela, coloca o cabaré - que é o espaço para prostituição do corpo da mulher e como um lugar que não tem honra. E dá andamento as agressões verbais evidenciando o real motivo do desconforto com a interlocutora.

\footnotetext{
Aí falou que eu era nojenta, que eu era uma sapatãozinha sebosa, essas coisas assim bem.... me chamava de lixo, essas coisas assim bem pesadas. Aí disse que me queria fora da casa dela, que nem precisava pagar o último mês, essas coisas assim: 'só quero você fora da minha casa até o final dessa semana, porque você tá sujando minha casa. (MALVA, 20 anos)
}

A interlocutora pode compreender que mesmo residindo fora da sua cidade de origem, a vigilância era ainda presente. Além disso, pode perceber como o preconceito quanto a homossexualidade propicia a caracterização da lesbianidade como algo digno de repulsa e nojo. Com isso, as lésbicas são constantemente submetidas a processos de higienização e exclusão. E esse episódio teve um efeito na forma como Malva percebia que estava constituído seu modo de ser e viver.

Mas aí eu me dei conta que eu tinha que esconder um pouco quem eu era até aqui, ne? Que ninguém me conhecia, eu disse: 'eu preciso ser aquela hétero para eu poder morar numa casa, que eu vou pagar com meu dinheiro' e ai por um tempo eu tive esse medo, de dizer assim um pouco, porque sempre perguntam, 'vai morar com quem? o que é 
seu?'... tipo entrevista de emprego, quase... parece que eu vou ganhar quase para morar na casa. E aí eu menti, menti... fui uma pessoa totalmente o contrário, ne? (MALVA, 20 anos).

Esse episódio leva Malva a questionar se sempre seria vista de maneira estigmatizada, como aponta o trecho abaixo:

\begin{abstract}
E aí eu fícava no início muito, meu receio era esse medo, de como a sociedade ia reagir, eles iam me ver como uma estudante? Eles iam me ver como uma garota boa, que tira notas boas, que se esforça ou como uma sapatão? E aí os meus vizinhos, eles iam passar e iam me passar e ia me dar bom dia, boa tarde quando passasse na escada ou eles iam virar a cara porque eles me viram com a minha namorada e sabe que ela não é só uma amiga? Porque no começo eu comecei a negar, ne? Quando eu me mudei a dona do apartamento disse ah, é tua irmã? Eu poderia ter dito é minha namorada, mas eu não consegui, porque me deu um medo, de ser tratada diferente, de quando eu fosse reclamar de alguma coisa ela não quisesse atender, ou de me colocar para fora. (MALVA, 20 anos).
\end{abstract}

Isso levou a mesma a se avaliar quando a quem era e como era percebida, afetando o seu modo de subjetivação, como aponta Lívia Toledo (2008, p. 11): “A influência dos processos de estigmatização está no sentido da captura, do condicionamento, do enclausuramento da vida, desfalcando oportunidades de vida dos processos de subjetivação, condicionando-os a uma essência sexualizada. A partir de abertura a possibilidades de vivência, é possível sair dessa captura por meio de linhas de fuga". Além disso, Junqueira (2011) coloca o quanto os dissidentes sexuais precisam se sobressair em outras áreas da sua vida para não sofrer mais violências.

Assim, é possível perceber dois grandes movimentos no território, um grande acolhimento por parte de algumas pessoas, ou uma rejeição de tão grande tamanho que nos sentimos ameaçadas quanto a nossa segurança, inclusive física.

\title{
4.4 Construir e resistir: estratégias de negociação e resistência
}

Por mais que maneiras de adequação, controle e vigilância sobre as mulheres que se relacionam afetivo-sexualmente com mulheres possam ser exercidas, as mesmas buscam estratégias para vivenciar seus desejos e afetos. Com isso, esse trabalho desde o seu princípio se desenvolveu com o objetivo de apresentar o que pulsa, instiga, emociona e fortalece. Vem demonstrar a força da resistência e sobre todo o orgulho de ser quem/como é. 


\section{Revista \\ Debates Insubmissos}

Diante disso, serão apresentadas as estratégias utilizadas para vivenciar experiências afetivo-sexuais pelas interlocutoras em uma cidade no Sertão do Pajeú e que é conhecida nacionalmente pela cultura de Lampião e machismo. Considerando também ser uma cidade em constante diálogo com a ruralidade e seus aspectos.

A maioria das interlocutoras declararam que revelaram, acerca da homossexualidade, para a sua família e para pessoas que fazem parte das suas relações de proximidade. Colocam que o poder da norma heterossexual ainda é muito forte e que precisam dialogar constantemente sobre a temática nos lugares que circulam, já que entendem a necessidade de desnaturalizar práticas sobre as questões de gênero e sexualidade. Apesar da ciência de que o peso quanto o "desvio a norma" dificulta o diálogo, ainda assim avaliam que as mudanças acontecem em processo, e que já conseguem negociar e propor uma reflexão com algumas pessoas.

As interlocutoras do trabalho de Ana Maria Brandão (2015) também colocam que buscam meios para lidar com o estigma de apresentar uma sexualidade dissidente, seja demonstrando um "padrão heterossexual" para os que estão a nossa volta ou utilizam estratégias e "manipulam" as informações para que não saibam da homossexualidade, ou divulgam a orientação sexual sabendo que necessitarão lidar com as consequências.

Mesma estratégia foi também utilizada com os familiares, que aproveitavam situações em que a família estava reunida e assuntos em torno de gênero e sexualidade eram colocados em pauta para aprofundar as reflexões, pois acreditam que é uma forma de ir desmitificando como também é um modo de ir preparando os familiares para falar sobre suas relações afetivosexuais com mulheres.

As interlocutoras adicionam ainda a importância de se conhecer, como também de se informar sobre as discussões de gênero e sexualidade. Argumentam que no processo de descoberta a internet funcionou como uma importante ferramenta para alcançar mais informações sobre a homossexualidade, proporcionando que tivessem mais segurança e propriedade sobre o assunto.

Esse empoderamento sobre o assunto proporcionou a proteção diante de algumas violências, principalmente quanto a pressão de religiosos diante do posicionamento de 


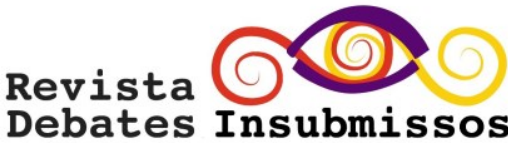

contrapor o que era postulado quanto a sexualidade. Além disso, reforçam o quanto as conversas com outras meninas por meio de chats foram relevantes para desmitificar o estigma e facilitar a aceitação enquanto dissidente sexual. E assim, podiam driblar a vigilância do contexto repressor.

O peso de contradizer a norma ainda faz com que algumas mulheres permaneçam se camuflando acerca do exercício da sua sexualidade. Três interlocutoras declararam que os familiares não sabem sobre sua dissidência sexual, porém explicam que apesar de sentirem medo da reação da família diante de uma revelação, isso não impede de vivenciar as relações afetivo-sexuais com mulheres.

Acrescentam que é um assunto que pode ser conversado, mas que percebem que muitas vezes é negado pela família por receio da confirmação. Assim, Marli Lima (2008) destaca a Política do tipo "você não me conta, eu não te pergunto", e coloca que é uma forma de evitar conflitos e tensões nas relações familiares. $\mathrm{Na}$ qual, as mulheres acreditam que os pais sabem acerca da homossexualidade, mas preferem não perguntar sobre, por não saberem como reagir diante da resposta.

Aqui destaca-se a dificuldade de ter que "assumir" uma homossexualidade, o que não acontece com os heterossexuais. É como se tivesse que apresentar que "desvia" de uma norma. Norma esta que foi construída socialmente e que para elas não faz sentido. Como colocado pelas entrevistadas, percebendo o exercício da sua sexualidade como igual a todas as outras pessoas, e assim como os casais heterossexuais não precisam anunciar que estão juntos e defender o porquê se relacionam daquela forma, também acreditam que não precisam sinalizar nem para a família que se relacionam com mulheres.

As interlocutoras destacaram ainda a preocupação de seus familiares com a repercussão, com os "outros", decorrente da revelação da homossexualidade, e que muitas vezes, era negociado a possibilidade dessa vivência acontecer, porém deveriam se manter discretas nas relações. Essa negociação se dá no intuito de garantir para a dissidente moradia e sustento, acreditam que esse acordo foi acentuado pois, no período, ainda não obtinham a maioridade e autonomia financeira. Da mesma forma, solicitam das colaboradoras a discrição com o intuito 
de evitar alguma forma de lesbofobia, enfatizando a dificuldade das pessoas em lidar com a temática.

Reforçam que se fossem expulsas de casa chamaria a atenção da vizinhança e de parentes da família extensa, e precisariam lidar com a temática que estava causando incômodo. Discorrem que existe um acordo implícito com os familiares, no qual vão poder se relacionar com mulheres, mas deverão ter cuidados quanto as demonstrações de afeto. Descrevem que em lugares que tem a presença de casais héteros com crianças evitam ter ações de carinhos com suas parceiras, é o modo de respeitar esse grupo, mas como também de prevenir alguma violência.

Entretanto, em alguns lugares são mais propícias as demonstrações de afeto, como também se sentem mais protegidas, mesmo que não conheçam as pessoas que possam estar presentes, mas é como se demarcassem que naquele território isso é possível.

Como algumas não tem sua sexualidade revelada para a família se utilizam da estratégia de apresentarem-se como amigas para "camuflar" suas parceiras. Como apresentado nas citações abaixo:

Por que os lugares que eu ia para ir ver a minha namorada, no caso, era ou na casa dela ou na concha, meus pais nunca vão na concha e eles nem imaginam que eu voltei a andar lá. Então tipo, sempre foi tranquilo e ir para os cantos... tipo quando a gente vai para alguma festa que eu sei que eles vão também, eles perguntam com quem tu vai eu digo, só que tipo nunca tá só eu e Angico, tá eu, Angico, Jitirana, Beatriz ${ }^{13}, \ldots$ entendeu? (QUIPÁ, 19 anos).

A vantagem das amizades entre mulheres apresentarem sempre uma proximidade maior, já que somos constantemente incentivadas a sermos amorosas, fazia com que os pais da interlocutora não percebessem que existia uma relação afetivo-sexual com uma das meninas do grupo. Assim, como todo grupo favorecia a proteção do casal.

A mesma estratégia que utilizava com a menina do EJC porque eu ia deixar ela em casa, ela ia me deixar em casa aí ficava nisso...dormiam uma na casa da outra, uma coisa supernormal. (QUIPÁ, 19 anos).

Como aponta Cynthia Cancissu (2007) que geralmente a família de origem costuma passar por uma fase de adaptação quando ocorre a revelação da homossexualidade feminina e

\footnotetext{
${ }^{13}$ Nome fictício
} 
que muitas vezes se afastam desse familiar para fazer a elaboração. Em consequência, as lésbicas tendem a buscar na comunidade homossexual pessoas que possam oferecer esse suporte social necessário no momento, entretanto o que a autora reforça é que esses laços se estendem para após o período de tensão, e inclusive essa família escolhida pode ser constituída por familiares sanguíneos, amigos e ex-parceiras (característica das relações lésbicas).

Jitirana relatou que diante da repercussão da revelação, seus irmãos colocaram que a apoiariam, mas que ela aliviasse os embates e "que não tentasse impor aquilo para família" (sic), já que sua mãe havia apresentado um quadro depressivo e estava precisando de cuidados. E o assunto trazia muitos conflitos e tensões por seus pais não aceitarem a homossexualidade. Ainda com relação as famílias, as mesmas destacam que com o passar dos anos, as famílias que tiveram resistência inicialmente começaram a se apresentar mais abertas para conversar sobre o assunto possibilitando outras negociações.

As entrevistadas reafirmaram por diversas vezes a importância dos outros dissidentes sexuais para o processo de auto reconhecimento e também nos momentos de tensão com a família de origem. Destacam que amigas e por vezes ex-namoradas exercem o papel de família escolhida, e que muitas vezes é um único suporte social em momentos de conflitos. Além disso, as interlocutoras colocam que a medida que foram relatando para os amigos acerca da sexualidade, foram aumentando o círculo de amizades de pessoas dissidentes.

Destacam a relevância dos movimentos sociais, ainda que não se percebem enquanto ativistas. Versam o feminismo como um movimento de grande impulso para se compreender e acima de tudo compreender as construções sociais que envolvem as mulheres. Somente uma interlocutora colocou que participa de movimentos sociais, e avultou a dificuldade em alguns momentos de negociar algumas pautas, apesar de haver um bom diálogo.

Quebrar o tabu de falar sobre gênero e sexualidade com mulheres e colocar que esse não é um assunto para ser discutido apenas entre mulheres (mãe e filha) mas com a família como um todo, vai desmitificando o papel de submissão e de resignação que nos é colocado. A desconstrução de um ideal de mulher que não pode falar sobre sexualidade vai se reformulando. Assim, também as colaboradoras da pesquisa vão se conhecendo e ficando mais fortes, e se 


\section{Revista \\ Debates Insubmissos}

sentem mais empoderadas para se posicionar em outros espaços, e não permitem serem subjugadas (pelo menos não facilmente).

As colaboradoras descrevem que permanecem no jogo de luz e sombra em que apenas revelam a homossexualidade em lugares que se sentem protegidas e que sabem que seu "segredo" possa ser mantido. Além disso, tem família que coloca constantemente a contrariedade diante da homossexualidade, mas as interlocutoras não permitem a interferência nas suas relações. Destacam que utilizam estratégias para se manterem discretas quando estão sob olhares de pessoas heterossexuais e que os dissidentes sexuais mais próximos auxiliam na cobertura para que os relacionamentos ocorram com segurança.

Foucault (1984) considera que os sujeitos estão submetidos a regimes de verdade, que contribui para a definição da verdade através das práticas. Porém não compreende o sujeito como totalmente assujeitado, pois tem a possibilidade de romper com tal assujeitamento. De tal modo, que através das práticas de si o sujeito tem a possibilidade de refletir sobre seus modos de vida, regular práticas e negociar entre o assujeitamento ou o rompimento das normas construídas socialmente. Abreviando, assim como a heterossexualidade é colocada como verdade única sobre os modos das pessoas se relacionarem, as mesmas podem romper com essa lógica, mas isso irá repercutir na relação consigo, com outros e com o mundo.

O autor ainda coloca que "onde há poder há resistência", já que estamos todos submetidos a jogos de poder e por mais que não seja possível nos isentarmos das construções sociais a que somos submetidas, podemos construir novos modos de negociar com as mesmas. Esse capítulo vem reforçar o proposto pelo autor. Destacando que fazer resistência não é apenas contrapor o que é instituído, mas é fazer disso um processo criativo.

Onde a restrição pode se tornar criação. É re-criar, mudar, arquitetar, potencializar... é inventar estratégias e manobras. É sair do mesmo, ainda que em território com forte vigilância e controle, onde as violências se tornam mais acentuadas pelas relações de proximidade. As interlocutoras fazem resistência quando reinventam em um contexto, onde a autoridade masculina se faz tão presente. Estão colocando cotidianamente suas existências como forma de resistência, onde costumam ser espaços imperados pelo forte machismo e patriarcado. 


\section{Revista \\ Debates Insubmissos}

E como Cheryl Clarke (1988, p.1) destaca "Não importa como uma mulher viva seu lesbianismo - no armário, na legislatura ou na rêcamara. Ela se rebelou contra sua prostituição ao amo escravista, que corresponde à fêmea heterossexual que depende do homem". Revelar a sua dissidência sexual socialmente não é a única forma de resistir. É preciso negociar com os desdobramentos da revelação da orientação sexual. E buscar meios de resistir ao esgotamento da saúde mental diante dos impedimentos. É resistência quando promove debates em contextos tão tradicionais. É resistência por tentar mudar o contexto que o cerca.

Mas como seriam resistência? São resistência, quando não aceitam que seus corpos sejam moldados e produzidos para uma lógica heteronormativa, que exclui seus desejos e afetos. São subversivas quando extrapolam o mesmo, quando rompem a inteligibilidade sexo/gênero e desejo sexual. Por quebrar as lógicas, gênero e sexualidade e, sobretudo em um contexto que tem como característica o apego às tradições. Resistem quando negam as prescrições sociais para a feminilidade. Quando subvertem tudo o que historicamente lhe é colocado como obrigação.

\section{CONCLUSÕES}

Atualmente, a maioria das interlocutoras se apresentam enquanto lésbicas, mas descreveram as dificuldades encontradas no processo. Citaram que primeiramente perceberamse interessadas por meninas próximas e que negociavam o contato mais íntimo através das brincadeiras. Não tinham consciência do que estava acontecendo, mas através das orientações implícitas por familiares, compreendiam aquilo como algo que não podia ser verbalizado com qualquer pessoa.

Como tais desejos precisavam ser mantidos em segredo, as buscas pela temática se deram através da internet. Meio que proporcionava confidencialidade e trocas com meninas que vivenciavam as mesmas situações. A medida que se apropriavam quanto a temática e sobre seu corpo, foram buscando estratégias de negociar com o contexto em que viviam. Negociações estas com família, amigos e parceiras. 


\section{Revista \\ Debates Insubmissos}

Essa proteção ofertada pela internet para se reconhecer a homossexualidade feminina, ainda favorece as interações afetivo- sexuais. O uso de aplicativos sociais se destaca como meio que proporciona a aproximação das dissidentes, assim como forma de manobrar a vigilância e exposição. Como ponto de destaque das interações afetivo-sexuais entre mulheres foi dado ênfase ao Rebuceteio, como uma rede de conexão em que várias mulheres já se relacionaram afetivo-sexualmente entre si. Porém, não foi encontrada nenhuma literatura sobre o assunto.

Buscamos ainda compreender o uso dos espaços de sociabilidade e as negociações com o território. As entrevistadas destacaram a Praça da Concha da cidade e o bar Espaço Concha's como locais em que os afetos entre homossexuais são autorizados, constituindo ali como um gueto homossexual, onde o que acontece ali, permanece ali. E que algumas negociações são feitas quando acontece algum evento do município no espaço.

Com relação as especificidades do território, a cidade ainda mantém suas tradições e representações ainda muito acentuadas em torno das figuras de Lampião e Maria Bonita, que por mais que seja um casal transgressor, permanece sendo heteronormativo e sustentando alguns padrões. Cabe destacar que pelo território ser restrito, as relações de proximidade são mais intensas como também a vigilância, abrindo possibilidade para a fofoca. Que funciona como instrumento para pressionar a família para exigir da interlocutora à adequação. Por outro lado, para as dissidentes sexuais que não tem Serra Talhada como sua cidade de origem abrese o leque de possibilidades, mesmo que com algumas restrições.

Ser marcada pela diferença faz com que repensemos constantemente sobre as normatizações e como nos adequar a elas, porém logo é perceptível que assumir tal posicionamento tem um preço para nossa saúde mental. Esse traço marca a diferença das demais pessoas, se caracteriza como estigma, e nem sempre é possível de ser acessado visivelmente. Aqui cabe a homossexualidade, que exige de cada uma a gestão de tal aspecto. A decisão por si só não é fácil já que precisa organizar vários fatores. Vários aspectos psicossociais precisam ser repensados quanto estamos entre a revelação e ocultamento.

Quantas colocações ouvimos no cotidiano sobre as lésbicas: que são masculinizadas, quando não esboçam como algo digno de nojo ou promíscuas, algo da ordem do impróprio e 
que as crianças não podem ter proximidade, que estão querendo se tornar homem ou sofreram desilusão com eles, e que existe uma lógica de passiva ou ativa que sustenta a relação delas. Todas essas construções sociais são reforçadas no cotidiano e as mulheres que se relacionam com mulheres precisam estar em constantes negociações.... principalmente desconstruindo-as para evitar algumas violências.

O que objetivo destacar nesse espaço é o quanto as normatizações construídas socialmente determinam um lugar para a mulher na sociedade e como a mesma deve se portar no mundo, inclusive sexualmente. É ressaltar o quanto as normatizações e suas imposições tão definidas nos fazem nos perceber inadequadas e "desajustadas" diante dos contextos em que estamos inseridos e afetando a forma como nos percebemos e nos relacionamos com as outras pessoas e contextos.

Trazer a força da resistência, ainda que precisando lidar com algumas formas de regulação, e vê-las aí vibrando, brincando, brindando.... é impressionante. É importante ver a potência desses encontros, ver o empoderamento dessas meninas, que muitas vezes me fez sentir uma velha diante da ânsia e da fé de vivenciar coisas maravilhosas. Também foi importante ouvir delas o quanto esse trabalho era relevante e até a curiosidade em saber como eu tinha conseguido estudar sobre tal temática, tipo... como tu conseguiu essa façanha?

Assim, compreendia como esse trabalho era importante, e como parece que temos tantas barreiras para quebrar, que ninguém se importaria e permitiria que nossas vivências fossem escritas. Se quiserem me colocar em caixinhas, que me encaixem. Mas que o que pude (re)aprender é que não posso perder a ânsia de viver do modo que me for conveniente, que só cabe a mim os caminhos que vou traçar, mas o mais importante é ter a consciência de que quem escreve a minha história sou eu.

Pela história delas e pela minha essa pesquisa foi constituída. Construída para aquelas que ainda sofrem muitas dificuldades por ser resistentes, por aquelas que foram expulsas de casa ainda muito novas, aquelas que sofrem com agressões de familiares, aquelas que vivem sob ameaças de vizinhos e precisam reforçar a segurança de suas casas, aquelas que são 
violentadas e assassinadas. Mas também para mostrar que mesmo mediante muita pressão, existem histórias boas para contar.

\section{REFERÊNCIAS}

BRANDÃO, Ana Maria. A Gestão do Segredo: Homo-erotismo feminino e relações familiares e de amizade. Les Online, vol. 7, n 7, pp. 3 - 16.

CLARKE, Cherly. "Lesbianismo: unacto de resistência". In: MORAGA, C.; CASTILLO, A. Esta puente, mi espalda: vocês de mujeres tercer mundistas en los Estados Unidos. São Francisco: ISM Press, 1988, pp. 99-108.

Cancissu, Cynthia Regina Pemberton. Lesbians, family of origin and family of choise: a case study. 2007. 90 f. Dissertação (Mestrado em Psicologia) - Pontifícia Universidade Católica de São Paulo, São Paulo, 2007.

FONTANELLA, Bruno José Barcellos; RICAS, Janete; TURATO, Egberto Ribeiro. Amostragem por saturação em pesquisas qualitativas em saúde: contribuições teóricas. Cad. Saúde Pública, Rio de Janeiro, v. 24, n. 1, p. 17-27, Jan. 2008 . Disponível em: $<$ http://www.scielo.br/scielo.php?script=sci_arttext\&pid=S0102311X2008000100003\&lng=en\&nrm=iso $>$. Acesso em: 17 Ago. 2016.

FOUCAUlT, Michael. (1984). A Ética do Cuidado de Si como Prática da Liberdade. In op. cit. Vol. V.

FLICK, Uwe. Introdução a pesquisa qualitativa. 3.ed. Porto Alegre: Artmed, 2004.

GIBBS, Graham. Análise de dados qualitativos. Tradução: Roberto Costa. Consultoria, supervisão e revisão desta edição Lorí Viali. Porto Alegre: Artmed, p. 80-96, 2009.

GREEN, James N. "Mais amor e mais tesão": a construção de um movimento brasileiro de gays, lésbicas e travestis. Cadernos Pagu, n. 15, p. 271-295, 2000.

JUNQUEIRA, Rogério (2011). Heterossexismo e vigilância de gênero no cotidiano escolar: a pedagogia do armário. In: Corpos, gêneros, sexualidades e relações étnico-raciais na educação. 2011, p. 74-92. Disponível em:http://porteiras.r.unipampa.edu.br/portais/sisbi/files/2013/07/Corpos-2011.pdf. Acesso em: 29 jun. 2018.

LOURO, Guacira Lopes. Gênero, sexualidade e educação - Petrópolis, RJ Uma perspectiva pós-estruturalista: Vozes, 1997. 
LOURO, Guacira Lopes. Pedagogias contemporâneas. (2008) Gênero e Sexualidade: Pedagogias Contemporâneas. Pro-Posições. Campinas, n. 2. v. 19. mai/ago. 2008. Disponível em: http://www.scielo.br/pdf/pp/v19n2/a03v19n2.pdf. Acesso em: 29 jun. 2017.

MISKOLCI, Richard. O armário ampliado - notas sobre sociabilidade homoerótica na era da internet. Revista Gênero, Niterói, v. 9, n. 2, p. 171-190, 2009. Disponível em: http://www.revistagenero.uff.br/index.php/revistagenero/article/view/88/64. Acesso em 15 nov. 2018.

NORBERT, Elias. Os estabelecidos e os outsiders: sociologia das relações de poder a partir de uma pequena comunidade. Rio de Janeiro: Zahar, 2000.

RIOS, Luís Felipe. $O$ feitiço de Exu: um estudo comparativo sobre parcerias e práticas homossexuais entre homens jovens candomblesistas e/ou integrantes da comunidade entendida do Rio de Janeiro. 2004. Tese (Doutorado em Saúde Coletiva) - Universidade Estadual do Rio de Janeiro, Instituto de Medicina Social, Rio de Janeiro, 2004.

TOLEDO, Lívia Gonsalves. Estigmas e estereótipos sobre as lesbianidades e suas influências nas narrativas de histórias de vida de lésbicas residentes em uma cidade do interior paulista. 2008. 234 f. Dissertação (mestrado) - Universidade Estadual Paulista, Faculdade de Ciências e Letras de Assis, 2008. Disponível em: http://hdl.handle.net/11449/97601. Acesso em: 10 de jun. de 2017

VINUTO, Juliana. A amostragem em bola de neve na pesquisa qualitativa: um debate em aberto. Temáticas, Campinas, 22, (44): 203-220, ago/dez. 2014 